\title{
Stakeholder Engagement in Marketing
}

By Dr. Samantha Miles ${ }^{1}$ and Dr. Kate Ringham ${ }^{2}$

Keywords: relationship marketing, stakeholder theory, stakeholder marketing, ladder of stakeholder engagement, value creation

\begin{abstract}
It has long been recognised within the stakeholder management literature that value is enhanced through meaningful stakeholder relationships based on trust, commitment, loyalty and transparency. This resonates with developments within the marketing literature whereby the organization-centric, transaction-based, buyer-supplier dyad focus of mainstream thinking has faced criticism for failing to understand the complex stakeholder networks that create and destroy value. Relational-based co-creation associated with relationship marketing, and the holistic approach embedded within stakeholder marketing, specifically address such criticisms. These represent an exciting new frontier for marketers. This chapter aims to add to the stakeholder marketing literature through the development of a marketing ladder of stakeholder engagement. The ladder of stakeholder management and engagement proposed by Friedman and Miles (2006) is reconfigured to reflect contemporary thought in relation to how a closer consideration of stakeholder management techniques can help to build trust and foster loyalty within the marketing function.
\end{abstract}

\footnotetext{
${ }_{1}^{1}$ Dr Samantha Miles, The Oxford Brookes Business School, Oxford Brookes University, Oxford, OX3 0BP

${ }^{2}$ Dr Kate Ringham, Oxford School of Hospitality Management, Oxford Brookes University, Oxford, OX3 0BP
} 


\section{Introduction}

It has long been recognised by proponents of stakeholder theory that value is enhanced through meaningful stakeholder relationships based on trust, commitment, loyalty and transparency (Freeman, 1984). This resonates with developments in the marketing literature whereby contributors acknowledge that a focus on a narrow set of stakeholders (customers, consumers and shareholders) is inappropriate as it fails to capture the complex stakeholder networks that create and destroy value. For Grönroos $(1994 ; 1996)$ this represented a 'paradigm shift' within marketing, moving away from a managerial perspective that viewed consumers as a source of cash to be exploited, towards relationship building, relationship management and viewing customers as co-producers and co-creators.

Relationship marketing has received a lot of attention from marketing academics (e.g. Aherne et al., 2005; Conway and Whitelock, 2007). This area of marketing adopts the same language as stakeholder theorists: both disciplines speak of collaboration, interaction, trust, empathy, reciprocity, commitment, symmetry, and transparency. Nevertheless, apart from a few exceptions (see for example Ferrell and Ferrell 2008; Maignan and Ferrell, 2004; Maignan et al., 2005; Stearns et al., 1996; Whysall, 2000), stakeholder applications to the marketing context have historically been partial and restricted, simply incorporating additional stakeholders within empirical analysis or recognizing multiple stakeholder interests (Hill and Martin, 2014). Stakeholder marketing emerged (Bhattacharya and Korschum, 2008) in response to this criticism.

The growing body of literature on stakeholder marketing recognises the potential benefits for marketers to recognise, map, analyse and evaluate the value adding, and detracting, activities of stakeholder networks along the marketing value chain (Hillebrand et al., 2015; Hult,et al., 2011; Mena and Chabowski, 2015). Stakeholder marketing explicitly recognizes that stakeholder interests are interrelated and value creation is driven by stakeholder networks. The emphasis on the value of relationships with stakeholder networks to improve customer experiences, and address societal concerns and sustainability, has been described as a "Kuhnian shift ... [which] ... significantly bends the marketing worldview" (Achrol and Kotler, 2012:35), and an opportunity for marketers to become more involved in strategic decision-making (Hillebrand et al., 2015; Webster and Lusch, 2013). This field of enquiry, yet to fully emerge (Kull et al., 2016), presents an exciting new frontier for marketers. 
This chapter makes a contribution to the stakeholder marketing literature by exploring the applicability of a recognised stakeholder theory model to stakeholder marketing. The ladder of stakeholder management and engagement proposed by Friedman and Miles (2006) is reconfigured to reflect contemporary thought in relation to how a closer consideration of stakeholder management techniques can help to build trust and foster loyalty within the marketing function. Before the proposed model is presented we provide a brief discussion of stakeholder theory and the stakeholder marketing literature. This leads on to a discussion of the attributes of relationship quality derived from both perspectives to inform the marketing ladder. Finally conclusions are drawn which highlight implications for future research.

\section{Stakeholder Theory}

Stakeholder theory is often referred to as an amalgamation of eclectic narratives (Gilbert and Rasche, 2008) or an umbrella concept that captures a range of thinking in relation to stakeholder management, stakeholder engagement, stakeholder power, stakeholder influencing strategies and so forth. Miles $(2017 \mathrm{a} ; 2017 \mathrm{~b})$ presented a systematic overview of stakeholder concepts and ideas, demonstrating how these narratives interconnect into a coherent frame of reference that emphasise the need to attend to a wide range of stakeholders rather than prioritising shareholders, and how to achieve this. We refer to this body of literature as 'stakeholder theory'.

Freeman (1984) argued that managers should consider all organization-stakeholder relationships as part of strategic management and many authors argue that this is good for business, culminating in enhanced brand and reputation (e.g. Harrison et al. 2010; Hillman and Keim 2001). If a relationship is to endure it requires an investment of time, active multiway interaction, honesty and transparency to build trust and commitment (Freeman, 1984; Freeman et al., 2010; Phillips 2003). So, a relational approach to stakeholder management is based on integrity and fairness (Bosse et al., 2009) and is more likely to contribute to social welfare than the more traditional transactional approach (Bridoux and Stoelhort, 2016). It is therefore 'the right thing to do', regardless of cost or accruing of benefits (Donaldson and Preston, 1995).

Central to stakeholder theory is the notion of value creation. Organizations create and destroy value through trade and this is achievable because stakeholders supply organizations with resources. Stakeholders and organizations come together, through supportive 
collaborative action, to create value that neither party could have created on its own (Crane et al., 2014; Freeman and Leidtka, 1997). This can be viewed from a stakeholder value chain perspective in which managers identify value-creating projects, financiers invest funds, the local community and regulators grant development permissions, employees provide human capital, suppliers provide inputs, and, customers buy into the output. Competitive advantage is generated through the development of stronger relationships which drive growth and create value by enhancing yields, increasing efficiency and resource use, and reducing externalities and societal harm, leading to cost reduction (e.g. reduced accident rates, pollution penalties or clean-up costs).

The networks that stakeholders form affect how stakeholders influence the firm and how the firm responds to these influences, suggesting a need to undertake coalition analysis to evaluate the commonality of behaviours and interests of stakeholder groups (Freeman, 1984). Dense ties between and within stakeholder groups facilitate communication through the transfer of norms and expectations: the greater the density of stakeholder networks the higher the potential to help or harm the organisation (Rowley, 1997). Bridoux and Stoelhort (2016) argued that contributions to joint value creation are influenced by how individuals perceive their relationships relative to that of others, emphasizing the need to explore psychological and sociological factors evident in stakeholder networks that may have adverse impacts on the stakeholder's willingness to engage in value creation. This highlights the need for stakeholder management to identify solutions that avoid situations in which stakeholders realign behaviour downwards and reduce value creation opportunities.

\section{Stakeholder Marketing}

It has long been recognized that marketers could increase firm value if a wider set of stakeholders were considered beyond customers (Christopher et al., 1991; Miller and Lewis, 1991; Polonsky and Ottman, 1998; Polonsky et al., 1999) or by building lasting stakeholder relationships (Bejou, 1997; Podnar and Jancic, 2006). Payne et al. (2005) argued that the external environment should not be viewed as an uncontrollable variable but as a source of indirect value creation, through customer interaction in a number of markets (referral, employee, influencer, internal and supplier markets). Consequently stakeholder thinking has influenced a number of strategic marketing management models (Kotler; 2003; Maignan et 
al., 2005; Maignan and Ferrell, 2004; Murphy et al., 2005; Polonsky, 1996; Polonsky and Scott, 2005).

A revised perspective, known as relationship marketing, emphasised building long-term relationships by developing trust so that the objectives of all parties are met and future service is improved (Aherne et al., 2005; Berry, 1983; Conway and Whitelock, 2007), leading to enhanced profit and sales growth (Palmatier et al., 2006). The relational perspective was extended to include customers as collaborators, co-producers and co-creators (Bendapudi and Leone, 2003; Prahalad and Ramaswamy, 2004; Vargo and Lusch, 2004) with an adaptive position within the supply chain. The extent and diversity of customer experience, knowledge and skills can be used advantageously through joint problem solving to improve product or service delivery and create a competitive advantage (Payne and Frow, 2006; Payne et al., 2009). Polonsky and Ottman (1998) highlighted the advantages of customer input into the design of new products from the opportunity stage through design, testing, introduction and life-cycle management. This recognises the potential increased value in actively engaging customers in co-production as part of a customer relationship management strategy. Whilst co-creation presents a mind-set change in the way marketers view customers (Bharti et al., 2015) the focus of relationship marketing predominantly remains with buyer-supplier relationships (see Payne and Frow, 2006; Payne et al., 2009). Consequently relationship marketing has been criticised for failing to progress significantly beyond the recognition of multiple stakeholder interests or merely extending empirical analysis to include additional stakeholders (Hill and Martin, 2014; Mena and Chabowski, 2015).

This criticism has been addressed through the development of the concept of stakeholder marketing (Bhattacharya and Korschum, 2008). This is considered to be a new frontier in marketing (Mena and Chabowski, 2015) concerned with "maintaining value through exchange relationships with multiple stakeholders" (Hult et al., 2011:57). Hillebrand et al. (2015) noted that stakeholder marketing differs substantially from a traditional marketing perspective in that proponents recognise that 1. Stakeholder interests are interrelated, not independent; 2. Value creation is driven by stakeholder networks not by the firm alone; 3 . Customer primacy is inappropriate, given the above. Hillebrand et al. (2015) criticised the buyer-supplier dyad focus of mainstream marketing literature and argued that value creation can only be understood by exploring the impact of complex stakeholder networks within the marketing function. Mena and Chabowski (2015) evidenced that simply responding to stakeholders does not guarantee enhanced value creation as it is the manner in which 
companies respond that is important. They advocated the use of more expansive stakeholderfocused organization learning, whereby organizations develop new stakeholder-related knowledge activities and learn from past actions to enable enhanced understanding of, and response to stakeholders' needs. Mena and Chabowski (2015) argued that this approach more accurately reflects the complex environment in which organizations now operate, in which control over marketing activities have become dispersed and decentralized (Hillebrand et al., 2015), and where value is created through stakeholder networks (Hult et al., 2011). Stakeholder marketing is still in its infancy, with much of the extant contributions focusing on conceptual papers. In adding to this literature we now turn our attention to the reconfiguration of a recognised stakeholder theory model, the ladder of stakeholder engagement (Friedman and Miles, 2006).

\section{A Marketing Ladder of Stakeholder Engagement}

\section{The Ladder of Stakeholder Engagement}

There are many stakeholder models that offer practical advice on how to manage stakeholder relationships (e.g. Freeman, 1984; Savage et al., 1991), how to prioritize conflicting claims (e.g. Mitchell et al., 1997), how to predict stakeholder influencing strategies (e.g. Friedman and Miles, 2002; Frooman, 1999) or how stakeholders use networking capabilities (e.g. Rowley, 1997). Few stakeholder models have been applied to the marketing context. Given the external facing nature of marketing we have selected the ladder of stakeholder management and engagement (see figure 1) proposed by Friedman and Miles (2006) for reconfiguration to the marketing function. The ladder illustrates 12 levels of stakeholder engagement, ranging from reactive, non-participatory exercises associated with strategic, public relations (PR) exercises, to holistic, proactive and collaborative engagement characterised by mutual dependency, risk sharing, empowerment and trust.

\section{Insert figure 1 here}

At the lowest level is non-participation relating to one-way information releases differentiated into three levels: 'Manipulation', Therapy' and 'Informing'. Part of PR management, 'manipulation' is used to skilfully manoeuvre opinion to change stakeholder expectations. To align opinion companies may intensively bombard stakeholders with selflaudatory materials. Some examples, aimed at curing an ideological gap between 
stakeholder and corporate opinion, relate to 'therapy'. 'Informing' is positioned higher on the ladder as it encompasses activities predicated out of transparency, not manipulation, although in practice this may be difficult to distinguish.

The next category of levels is tokenism. Here stakeholders have a voice but lack influence. 'Explaining' activities may be used to reduce conflict, dispel misconceptions or facilitate buy-in from stakeholders, if the stakeholders perceive the relevance of the issue involved. 'Placation' may provide opportunities for stakeholder influence, through advisory panels or task forces but only to the extent that the firm decides to act upon advice solicited. Stakeholder engagement at this level may be political, for example to gain legitimacy. If stakeholders are informed of, and participate in, the decision- making process, they are more likely to agree with the outcome, leading to enhanced public perception (Darnall and Jolley, 2004). Seeking real consultation through dialogue differentiates level 6 'Consultation' from lower levels, where stakeholder interests and opinion are solicited. Stakeholders are more involved in level 7 'Negotiation' as the stakeholders invest on a conditional basis. If conditions are not met within a reasonable timeframe, stakeholder support is withdrawn e.g. employees strike, investors divest or suppliers terminate contracts to supply goods. As negotiation occurs prior to reaching a final decision stakeholders have power to influence the decision, although the extent of power is dependent on the substitutability of resources (Frooman, 1999).

Levels 8 (Involvement) and 9 (Collaboration) are degrees of involvement. These are resource intensive proactive forms of engagement. Organization-stakeholder goals are compatible and decision-making power is afforded to stakeholders, for example roundtable participation to draft proposals. Involvement may be stakeholder initiated, for example using constructive dialogue to influence organizational behaviour, as popularised by the socially responsible investment sector (Friedman and Miles, 2001) or raising a shareholder resolution over environmental management policies. 'Collaboration' uses strategic alliances of complementary skills or resources to pursue mutually beneficial goals, which include corporate sponsorships and product endorsements.

The top levels of engagement relate to degrees of stakeholder power. Level 10 'Partnerships' and level 11 'Delegated Power'. This is dependent on high levels of trust and strategies need to be collaborative which build on interdependences. The final level is 'Stakeholder Control'. Examples are exceedingly rare as this requires genuine stakeholder empowerment (see Kochan and Rubinstein's (2000) discussion of the Saturn project at General Motors). 
Despite the step-wise progression implied, it is inappropriate, and undesirable, to conduct all engagement at the highest levels, as stakeholder management is resource constrained and issue and time sensitive. Nevertheless engagement activities at the higher levels are associated with stronger relationship building underpinned by trust and commitment. Likewise, used in isolation, non-participation is associated with treating stakeholders with neglect or contempt and would be contrary to a stakeholder management philosophy.

In analysing the applicability of the ladder to a marketing context it is necessary to explore the antecedents of a successful stakeholder-organization relationship from the marketing perspective and to compare this with stakeholder management thinking. This is addressed in the next section.

\section{Dimensions of Relationship Quality}

Stakeholder marketing is concerned with the development of successful, long-term, mutually beneficial relationships. What constitutes relationship quality may be easy to discern but it is difficult to analyse. Marketers have differentiated between dimensions, antecedents and consequences of relationship quality but there is no accepted framework for analysis, with multiple variables identified (Athanasopoulou, 2009). Table 1 summarizes the main variables highlighted in this literature. Stakeholder theorists refer to aspects of relationship quality but have not analysed this concept with equal consideration. In this section we take the notion of relationship quality from both perspectives. This provides three dominant dimensions, two which dominate the marketing literature: trust and commitment (Coote et al; 2003; Goodman and Dion, 2001), and power that, whilst recognised as a dimension of relationship quality within the marketing discipline, is central to stakeholder management (Mitchell et al., 1997).

Insert table 1 here

- $\quad$ Trust

Trust (D22) is the willingness to rely on an exchange partner in whom one has confidence (Orth and Green, 2009). It is a complex dimension, closely linked to other relationship 
quality variables, for example trust is central to leveraging customer lifetime value (Aurier and N'Goala, 2010; Bove and Johnson, 2006; Chaudhuri and Holbrook, 2001). Palmer and Huo (2013) argued that trust is positively correlated with integrity, and benevolence (aligned with D15: reciprocity and D11: empathy) predictability (inverse of D23: uncertainty) and competence (D5), whilst Morgan and Hunt (1994) demonstrated a positive correlation with co-operation (D7). Trust is inversely related to the organization's opportunistic behaviour (D13) (Morgan and Hunt, 1994) and uncertainty (D23) (Bell et al., 2005; Morgan and Hunt, 1994). A number of authors (e.g. Crosby and Stephens, 1987; Doney and Cannon, 1997; Sirdeshmukh et al., 2002) relate trust to multi-facets in consumer evaluations extending beyond trust in the organization to include trust in the contact person and core service.

Trust is embedded as a concept within stakeholder theory (Clarkson Center for Business Ethics, 2002; Swift, 2001), in which stakeholder relations should be based on mutual trust and cooperation (Jones, 1995). Calton and Kurland (1995) recognised three forms of trust in the stakeholder engagement literature: calculus-based trust; knowledge-based trust, and; identification-based trust. Whilst nomenclature varies, these parallel marketing concepts of calculative-based trust, cognitive-based trust and affective-based trust. Calculus-based trust is based on economic switching costs (D21), or terminating the relationship and the benefits associated with attractiveness of continuing the relationship (D1). Knowledge (cognitive)based trust develops with experience: future bonding is more likely if a firm has demonstrated competence (D5) in previous transactions, for example through demonstrating high levels of service quality (D19). Identification (affective) trust is associated with the principles of reciprocity (D15) and empathy (D11) with regards to meeting stakeholder needs. This is a stronger form of 'affective trust' which is evident in examples of customers as co-producers.

Given the importance of trust in both literatures trust is explicitly included in the reconfiguration of the ladder of engagement. Calculative-based trust is associated with lower levels (1-3) of engagement, whereas cognitive trust requires stronger bonds and expectations of competence generated from reputation or experience, and would span from 'Explaining' to 'Involvement'. Effective higher level engagement ('Collaboration upwards) has to be underpinned by good citizenship created from integrity, fairness, empathy and reciprocity which are associated with affective trust. 


\section{- Commitment}

Commitment (D3) relates to the strength of the relational ties between parties and the enduring desire to invest resources to maintain a relationship. The strongest form of commitment is normative commitment derived from moral obligations (Gruen et al., 2000) and empathy (D11). An instrumental investment represents the weakest form of commitment, driven by self-interest and opportunistic behaviour (D13) (Gundlach et al., 1995) from an assessment of relationship benefits (D16) and the costs incurred of exiting the relationship (D21) if attractive alternative offers exist (D1). Two forms of psychological bonds are evident between these extremes. Firstly continuance commitment, associated with the feeling of being compelled to stay in a relationship, for example dependence (D10) arising from a customisation (D9) of the offering and leading to a lack of alternatives. Affective commitment is derived from shared values (D20) and belongingness, creating a willingness to remain in the relationship. Affective commitment positively impacts relationship bonds (D2) (Verhoef, 2003) and is underpinned by reciprocity (D15) and responsibility derived from shared values (D20) and goal congruence (D12).

Stakeholder theory is relatively silent on the issue of commitment but there are aspects of stakeholder engagement that provide interesting insights. Frooman (1999) argued that commitment is determined by concentration of suppliers and non-substitutability of the offering (D10), controllability, non-mobility of the stakeholder, and essentiality (the relative magnitude of exchange and criticality). Rowley and Moldoveanu (2003) linked commitment to the psychological attachment derived from shared values (D20) and belongingness, and suggested that the degree to which a stakeholder group will be mobilized into action is dependent on interest and identity overlap (D20). Commitment is also aligned with stakeholder capacity and willingness to threaten or cooperate (Freeman, 1984). If both the potential for threat and the potential for cooperation are high, collaborative strategies should be sought, requiring high levels of commitment. Conversely no commitment is required if both the potential for threat and for cooperation (D7) are low (Savage et al., 1991). This is also related to conflict management, stemming from divergent stakeholder interests (Friedman and Miles, 2002; Frooman, 1999). Carroll (1979) proposed four conflict management strategies. Firstly, reactive strategies are aligned with opportunistic behaviour 
(D13) to promote brand or firm image. Defensive strategies involve attempts to alter stakeholder opinion to maintain relations through informing or educating activities, for example where legitimacy has been breached. Accommodative strategies involve listening to the concerns of stakeholders and aiming to fulfil their expectations. This will require cooperation (D7) and coordination (D8) to accomplish outcomes with which both parties to the transaction are satisfied (D18). Finally proactive strategies go beyond normal expectations to deliver high levels of satisfaction (D18) and enduring relationships built on the principles of goal congruence (D12), shared values (D20) and reciprocity (D15). Figure 3 illustrates how the dimensions of relationship quality are aligned to commitment and stakeholder strategies.

\section{Insert figure 3 here}

Commitment has been explicitly included in the marketing ladder of engagement. Instrumental commitment is associated with levels 1-3, whereas continuance commitment requires stronger bonds (levels 4-5). Affective commitment, based on shared values and reciprocity is reflected in levels 6-9. At the very highest levels (10-13) normative commitment is evident as this has to be underpinned by empathy and facilitated through proactive stakeholder strategies.

\section{- Power}

Power (D14) relates to "the ability of one individual or group to control or influence the behaviour of another" (Theron and Terblanche, 2010:390). Nguyen (2012) argued that asymmetric relationships emphasise power imbalances and provide scope for opportunistic behaviour (D13), whereas symmetric relationships are based on a commonality of interest (D12, D20) which promotes information sharing (D4). Consumer power increases with greater levels of mutual dependency (D10), as reflected in the extension of the role of consumers to collaborators, co-creators and co-producers of value (Bhalla, 2011). Conflict (D6) is positively correlated with power (Morgan and Hunt, 1994). Functional conflict, resulting in beneficial outcomes, and dysfunctional conflict, leading to negative outcomes, such as opportunistic behaviour (D13) are differentiated (Massey and Dawes, 2007).

Power is a recognised attribute for stakeholder recognition (Miles, 2017a; Mitchell et al., 1997) and is linked to resource-dependency. Frooman (1999) indicated that stakeholders 
who are dependent on the firm for resources are more committed to long-term relationships. He argued that the higher the resource dependency the greater the power to influence. Power is therefore associated with commitment (D3), dependency (D10) and relationship-specific resources (D17) (Frooman, 1999). Mitchell et al., (1997) classified power as coercive power related to physical force, utilitarian power derived from relationship-specific resources (D17), and normative power associated with moral obligations (D11, D15). Normative power is closely linked to trust (D22), dependence (D10) and commitment (D3). Miles (2017a) argued that power is the dominant stakeholder attribute, as without the power to influence the level of reciprocity will be low. Stakeholder power will be highly limited if both parties act independently and there is no firm commitment (D3), whereas stakeholders will have some power to influence corporate decisions if there is mutual dependency (D10) and intention to build long lasting relationships.

Bridoux and Stoelhort (2016) analysed four stakeholder relational models and concluded that the highest contribution to value creation was evident in 'communal sharing' situations as participants view themselves as part of a community and align the collective interest with their own (D12 goal congruence; D20 Shared Goals), facilitating co-ordination. This is aligned with normative power and empathy (D11). The lowest contribution was evident in 'market pricing' approaches. Power is derived from resources and behaviour is dominated by self-interest (D13). 'Authority ranking' models of behaviour rely on the hierarchal power from an asymmetric relationship, in which the firm is viewed as authoritative because of perceptions of legitimacy and competence (D5). This leads to lower levels of value creation when compared to 'equality matching', characterised by equivalent retaliation behaviour (D15 Reciprocity) stemming from shared understanding and viewing network participant as equal. The model adopted is reliant on individual personality traits and the perception of the firm's accountability and intention. Stakeholder engagement approaches, as illustrated in the ladder, can act as indicators of firm's accountability and intention. Bridoux and Stoelhort (2016) argued that in situations where there is a mismatch between higher personal relational models and lower firm relational models, stakeholders will either realign behaviour, leading to lower levels of value creation or sever the relationship. This provides justification for not focusing all stakeholder management activity at lower levels. Figure 4 illustrates how the dimensions of relationship quality are aligned to power from a stakeholder theory perspective. 
[insert figure 4 here]

Engagement activities at the very lowest level of the ladder not only fails to incorporate the stakeholder voice, but actively attempts to manipulate perception. In such situations stakeholders are powerless and have no say. Utilitarian power, associated with resource investment relate to 'Therapy' through to 'Consultation', depending on whether a market pricing approach or authority ranking approach is adopted by stakeholders. Normative power is only evident at the higher levels of the ladder, from 'Negotiation' or conciliation levels.

\section{A Stakeholder Marketing Ladder of Engagement}

We present a stakeholder marketing ladder of engagement in Figure 5. One-way stakeholder communications are included at the bottom of the ladder (e.g. promotions that inform customers of available offerings). Campaigns that aim to skilfully manoeuvre stakeholder expectations would be included under 'Manipulation'. Marketers need to be wary of targeting engagement at this level as many companies have been fined, or forced to remove adverts seen to be misleading. For example L'Oréal's advertisement for Olay's Definity eye cream was banned in the UK in 2009 for airbrushing wrinkles and its advert for Lancôme Génifique and Paris Youth Code skincare products banned in the USA in 2014 for claiming unsubstantiated scientific evidence (Federal Trade Commission, 2014). 'Therapy' does not involve a direct effort to control opinion but attempts to 'cure ignorance' or realign stakeholder expectations. Tesco (UK), for example ran the advertisement campaign "what burgers have taught us" in 2013 following accusations that own brand beef burgers and ready meals contained horsemeat. The full page 'apology' highlighted Tesco's current CSR approach to farmers and a pledge to change the way the industry works (Wheeler, 2013) in an attempt to change opinions of the media, pressure groups and consumers. These forms of engagement do not attempt to build lasting relationships through cognitive or affective trust but tend to be based on opportunistic behaviour associated with reactive or defensive strategies. 'Informing' engagement is used effectively by companies that sell complex products in which key benefits which are not easily discernible or communicated without demonstration, such as the longevity of Duracell batteries or the functions of the latest Apple i-phone. Packaging is a key element in informing strategies, as good packaging not only enhances the attractiveness of the offering and is influential in purchasing decision, but provides opportunities to inform the public of strategic messages to reinforce brand and 
corporate image. Successful engagement of this type therefore necessitates close coordination with packaging suppliers. Focusing marketing activities at lower levels will not achieve the advantages associated with stakeholder marketing, necessitating a mixed engagement strategy.

\section{Insert figure 5 here}

Marketing can enhance understanding and so 'Education' replaces 'explaining' from the stakeholder engagement ladder. 'Infomercials' are used by not-for-profit organisations to inform the public on health, social or environmental issues and by politicians during election campaigns. Education campaigns are less common with corporates, but have been used when responding to stakeholder pressure to rebuild reputational damage, prevent boycotts and to minimise loss in stakeholder value. British Petroleum's rebranding campaign to Beyond Petroleum in 2000 following a spate of environmental and social misdemeanours is a clear example (Macalister and Cross, 2000).

A further marketing-specific level has been added called 'Targeting'. Marketing has responded effectively to technological advancements in consumer behaviour and as a consequence is more advanced than other business functions at developing innovative data management systems to track and store stakeholder information which facilitates targeted cross-selling, up-selling and customisation of the offering. Data gathering has been extended by on-line retailers, such as Amazon and ebay, to include 'wish/watch lists'. The increasing need for third party support and increased data analysis logically extends the range of stakeholders that can impact the marketing function. For example, services such as Google AdWords pay per click on-line advertising enables adverts to be posted on-line in relation to frequent searches made by the user. Targeting is positioned at level 5 because it is a responsive strategy, responding to demographic/transaction data or consumer behaviour whilst remaining opportunistically driven.

'Placation' is also a responsive strategy aimed at addressing stakeholder concerns over issues such as packaging, labelling, CSR issues, quality of service and so forth. Whilst consumers may have a legitimate interest in such issues, the range of stakeholders raising these concerns can be wide. Consequently the 'marketing' response to these concerns needs to be fully informed by the relevant functional areas to ensure a consistent corporate message. For example, CSR marketing can increase customer commitment due to shared values and beliefs 
but it needs to be supported by appropriate CSR investment, as with Levi's 2010 'Go forth' campaign (Taylor, 2010), to avoid reputation damage via social media if CSR credentials are found inadequate. Stakeholder engagement may be positive or negative and include completing on-line reviews, contacting the company directly or word-of-mouth activity.

Marketers have long realised that collecting and responding to customer feedback is an essential part of delivering outstanding customer satisfaction. There are many forms that 'Consultation' can take including surveys, 'secret shopper', and social media forums. Some organizations have taken consultation to a higher level. For example DeWALT, operates an 'insight community' of over 10,000 end users of its power tools which gathers information on user needs, ideas and concerns (Dupre, 2015). The resulting collective wisdom enables DeWALT to undertake more confident product development decisions. This complements other data sources such social media analytics. Insight communities rely on stakeholders opting-in to the group and so attention needs to focus on how stakeholders are treated to ensure long-term relationships are formed.

'Conciliation' replaces 'negotiation' on the original ladder. This differs from 'Placation' to the extent that stakeholder concerns are accommodated rather than defended. A product recall offers an opportunity to demonstrate conciliation and whilst a product recall may appear a costly strategy, brand and share price will struggle to recover if a company fails to respond expediently to problems, particularly if human life is at risk. The iconic example of Johnson and Johnson and the recall of Tylenol in 1982 resulted in increased brand value for consumers and employees, and buoyant share price because of the proactive response to the isolated contamination of drugs by a disgruntled employee. This contrasts sharply with the slow response from Ford to recall vehicles fitted with faulty Firestone tires that led to 174 deaths and 700 injuries in the USA and subsequent \$590 million lawsuit bill (Greenwald, 2001).

Co-creation, such as Lego's 'Ambassador Program' in which consumers work with brands to create an improved offering informed by the consumers' needs and knowledge (Antorini et al., 2012) is classified as 'Involvement'. Mutual benefit is gained from customer input into the design of new products from the opportunity stage through design, testing, introduction and life-cycle management (Polonsky and Ottman, 1998). Co-creation can lead to low cost product development coupled with increased stakeholder loyalty and satisfaction derived from the sense of ownership in the brand that is created through stakeholder participation. There is no universal engagement approach, and some examples of engagement are more 
successful than others. Involvement such as co-creation is a change in mind-set in the way that marketers view stakeholders by acknowledging the value of the extent and diversity of knowledge, experience and skills held (Bharti et al., 2015). Success is facilitated by a culture of exchange and open communication, which may include the sharing of proprietary information with stakeholders. This is only possible if there is a high level of trust.

Involvement is differentiated from 'Collaboration', as in the former stakeholders are able to influence the company through ideas and feedback but the company still retains the balance of power and may decide how it uses information gathered. Collaboration may be as simple as an ideation contest in which winning idea is determined by stakeholder vote, as demonstrated by the 2017 campaign 'choose or lose' Walkers crisps brand at PepsiCo. Collaboration may involve a wider stakeholder group than consumers. For example the farmer owned company Arla Foods, developed Cravendale milk, through co-creation with farmers/owners (who wished to add value to their milk and investment), consumers (who desired longer use by dates), technical engineers who developed the ceramic filtration system to remove bacteria, and its packaging suppliers to provide an opaque bottle that prevented deterioration through light exposure. Collaboration may also relate to business-to-business models. For example, online market and hospitality services that work together to extend the reach of advertising for individual hotels and holiday accommodation.

Companies may engage in third party endorsements of products or corporate sponsorship to improve the offering through 'Partnership' engagement. For example Coca-cola partnered with WWF, donating \$2 million to help with the plight of polar bears (its animal mascot) and global warming. This may be a fraction of the $\$ 9.8$ billion advertisement budget but it is still a substantial contribution. The 'Coca-cola Artic Home' advert was launched in 2013 on the back of this, achieving a further $\$ 3$ million in donations from customers (Frazier, 2014). Genuine green or cause-related marketing may focus around such engagement but this may be viewed cynically if manipulated for image transfer.

Examples of 'Delegated Power' and 'Stakeholder Control' in the original ladder of stakeholder engagement are rare within business (Miles and Friedman, 2006) and this also applies to the marketing function. With the onset of the sharing economy examples exist where firms engage in joint ventures to develop products in business-to-business models (Payne and Holt, 2001), or share resources. 


\section{Concluding comments}

The ladder of stakeholder management and engagement proposed by Friedman and Miles (2006) is reconfigured to reflect contemporary thought in relation to how a closer consideration of stakeholder management techniques can help to build trust and foster loyalty within the marketing function in the modern business environment.

This model is firstly intended as a self-evaluating tool for marketers to use to map the range of activities undertaken. Both marketing and stakeholder theorists acknowledge that longterm relationships need to be based on loyalty and trust founded on empathy, reciprocity, commitment, transparency, fairness and collaboration. This should emanate from an underlying palpable ethical objective towards stakeholders rather than as a selective byproduct of opportunistic behaviour, as historically witnessed within the marketing function.

Relationship building, if sought, is promoted as a way to secure a strategic advantage through increased referrals and associated cost reductions and reduced opportunistic behaviour. These aims will not be achieved by focusing marketing activities at the lower levels of engagement as this will fail to develop long-term relationships and will miss the opportunity to unlock stakeholder knowledge and experience for product development. Organizations that adopt an ethical duty of care to their stakeholders gain in the long-term, especially if things go wrong as procedural fairness is central to retention. How organizations deal with product faults, the exercise of warranties and product recalls can be pivotal in terms of reputation management and repeat custom.

Relationship quality is dependent on procedural quality, responsiveness quality and quality of outcomes (Friedman and Miles, 2006) which extend beyond the direct sales experience to encompass after sales service provisions (Homburg and Griering, 2001). A retail organisation that refuses to accept responsibility for problems or refers complaints down the supply chain may reduce short-term costs but at the cost of lost reputation, dis-trust and high levels of customer attrition. In order to progress engagement to higher engagement levels marketers are advised to formalize procedures, provide facilities for stakeholders to initiate engagement and provide assurance that stakeholders are empowered to raise critical or time sensitive issues (Zadek and Raynard, 2002). This is particularly important in light of the findings from Bridoux and Stoelhort (2016) in which value creation potential can be eroded if stakeholders perceive firm relational models to be lower than personal relational models, 
thereby providing further justification for not focusing all stakeholder management activity at the lower levels of the ladder.

Secondly this model is intended to reveal the kinds of engagement activities that would be required in order to change focus, particularly where a stakeholder marketing approach is intended. Whilst a range of engagement activities are desirable, marketers are advised that in order to build relationships of enduring quality that they should concentrate on collaboration and interaction with stakeholders using a range of engagement strategies including some evident at the higher levels of the ladder. Marketers must recognise that long term relationship building requires personal and expert interaction and cannot be generated by systems driven data analysis.

Hillebrand et al. (2015: 412) argued that "Embracing a stakeholder marketing perspective and developing the associated capabilities may be a promising avenue to overcome the declining influence of marketing in firms". Despite academic advances in stakeholder marketing, the stakeholder focus in marketing remains narrow and does little to acknowledge the wider range of relationships that contribute to value creation (channel members, retailers, wholesalers, agents and sales representatives, manufacturers, warranty providers, customer service staff, internet advertising agents etc. ) but also the interconnectedness of stakeholders stemming from service constellations (Hillebrand et al., 2015). The sales experience is no longer a one-to-one experience with sales personnel, agent or retailer, due to online review sites, such as Trip Advisor or TrustPilot, and direct customer reviews via agent sites such as ebay or Amazon. In addition sales can be impacted by sourcing decisions, packaging and labelling and reputational issues. This is evident by the range of consumer boycotts due to poor environmental (e.g. pollution - Coca Cola, BP), social (e.g. tax avoidance - Amazon, Starbuck; human rights - Shell, Starbucks) or ethical (e.g. animal rights - Adidas, Air France) practices. This provides greater justification for marketers to adopt a stakeholder marketing approach as more effective stakeholder mapping exercises which capture the actual behaviour of all the marketing stakeholders would help to facilitate marketers to fulfil their objectives and devise appropriate engagement strategies. Stakeholder mapping techniques exist to identify resource dependency (Pfeffer and Salancik, 1978), proximity of stakeholder (Driscoll and Starik, 2004) and centrality of the organisation in the stakeholder network as a power determinant (Frooman, 1999) when identifying stakeholder influencing strategies and formulating corporate stakeholder strategies but there is limited application of such models within the marketing literature. This chapter has provided such an example. 
Whilst this is a conceptual effort, future research could test this model empirically through the development of propositions that explore the relationship between relationship quality determinants and engagement strategies, or via in-depth case analysis. 


\section{References}

Achrol, R.S. and Kotler, P. (2012). Frontiers of the marketing paradigm in the third millennium, Journal of the Academy of Marking Science, 40(1):35-52.

Antorini, Y.M., Muñiz, A.M. Jr. and Askildsen, T., (2012). Collaborating With Customer Communities: Lessons From the Lego Group. MIT Management Review, March $20^{\text {th }}$.

Athanasopoulou, P. (2009). Relationship quality: a critical literature review and research agenda. European Journal of Marketing, 43(5/6):583-610.

Aurier, P. and N'Goala, G. (2010). The differing and mediating roles of trust and relationship commitment in service relationship maintenance and development. Journal of the Academy of Marketing Science, 38:303-325

Bejou, D. (1997). Relationship marketing: evolution, present state, and future. Psychology \& Marketing, 14(18), 727.

Bell, S. J., Auh, S., and Smalley, K. (2005). Customer relationship dynamics: service quality and customer loyalty in the context of varying levels of customer expertise and switching costs. Journal of the Academy of Marketing Science, 33:169-183.

Bendapudi, N., and Leone, R. P. (2003). Psychological implications of customer participation in co-production. Journal of Marketing, 67(1):14-28.

Berry, L.L. (1983) Relationship marketing. In: L.L. Berry, G.L. Shostack \& G. Upah (eds) Emerging Perspectives on Services Marketing. Chicago, American Marketing Association, pp. 25-28.

Bharti, K., Agrawal, R. and Sharma, V. (2015). Value co-creation: literature review and proposed conceptual; framework. International Journal of Market Research, 57(4):571-603.

Bhattacharya, C.B. and Korschum, D. (2008) Stakeholder Marketing: Beyond the Four Ps and the Customer. Journal of Public Policy \& Marketing, 27(1): 113-116.

Bosse, D.A., Phillips, R.A. and Harrison, J.S. (2009). Stakeholder reciprocity and firm performance, Strategic Management Journal, 30:447-456.

Bove, L. L., and Johnson, L. W. (2006). Customer loyalty to one service worker: should it be discouraged? International Journal of Research in Marketing, 23(1), 79-91.

Calton, J. M. and Kurland, N. B. (1995). A theory of stakeholder enabling: giving voice to an emerging postmodern praxis of organisational discourse. In D. M. Boje, R. P. 
Gephart and T. J. Thatchenkery (Eds.), Postmodern Management and Organization Theory:154-177. London: Sage.

Carroll, A. B. (1979). A Three Dimensional Conceptual Model of Corporate Social Performance. Academy of Management Review, 4: 497-505.

Chaudhuri, A., \& Holbrook, M. B. (2001). The chain of effects from brand trust and brand affect to brand performance: the role of brand loyalty. Journal of Marketing, 65(2), 81-93.

Christopher, M., Payne, A. and Ballantyne, D. (1991), Relationship Marketing: Bringing Quality, Customer Service and Marketing Together, Butterworth-Heinemann, Oxford.

Clarkson Center for Business Ethics (The). 2002. Principles of stakeholder management. Business Ethics Quarterly, 12(2): 257-264.

Conway, T. and Whitelock, J. (2007). Relationship marketing in the subsidised arts: the key to a strategic marketing focus? European Journal of Marketing, 41(1/2):199-222.

Coote, L.V., Forrest, E.J. and Tam, T.W. (2003) An investigation into commitment in nonWestern industrial marketing relationships. Industrial Marketing Management, 32(7):595-604.

Crane, A., Palazzo, G., Spence, L. J., and Matten, D. (2014). Contesting the value of “creating shared value". California Management Review, 56(2):130-153.

Crosby, L. A., and Stephens, N. (1987). Effects of relationship marketing on satisfaction, retention, and prices in the life insurance industry. Journal of Marketing Research, 24:404-411.

Darnall, N., and Jolley, G. J. (2004). Involving the Public: When Are Surveys and Stakeholder Interviews Effective? Review of Policy Research, 21(4): 581-593.

Donaldson, T. and Preston, L.E. (1995). The stakeholder theory of the corporation: concepts evidence and implications. Academy of Management Review, 20, 65-92.

Doney, P. M., and Cannon, J. P. (1997). An examination of the nature of trust in buyer-seller relationships. Journal of Marketing, 61(2):35-51.

Dupre, E. (2015). Customer insight is DeWALT's power tool. Direct Marketing News, $20^{\text {th }}$ November.

Federal Trade Commission (2014). L'Oréal Settles FTC Charges Alleging Deceptive Advertising for Anti-Aging Cosmetics, 30 $0^{\text {th }}$ June. Accessed on $2^{\text {nd }}$ April 2016 at https://www.ftc.gov/news-events/press-releases/2014/06/loreal-settles-ftc-chargesalleging-deceptive-advertising-anti 
Ferrell, O. C. and Ferrell, L. (2008). A macromarketing ethics framework: stakeholder orientation and distributive justice. Journal of Macromarketing, 28(1):24-32.

Frazier, M. (2014). Should the polar bear still sell Coca-Cola? The New Yorker, $6^{\text {th }}$ November.

Freeman, R. E. (1984). Strategic Management: A Stakeholder Approach. Boston: Pitman Publishing.

Freeman, R. E. and Liedtka, J. (1997). Stakeholder capitalism and the value chain. European Management Journal, 15: 286-396.

Freeman, R.E., Harrison, J.S., Wicks, A.C., Parmar, B., and de Colle, S. (2010). Stakeholder Theory: the State of the Art. Cambridge University Press.

Friedman, A. L. and Miles, S. (2001). Socially Responsible Investment and Corporate Social and Environmental Reporting in the UK: An Exploratory Study. British Accounting Review, 33:523-548.

Friedman, A.L. and Miles, S. (2002). Developing stakeholder theory. Journal of Management Studies, 39(1):1-21.

Friedman, A.L. and Miles, S. (2006). Stakeholders: Theory and Practice. Oxford: Oxford University Press.

Frooman, J. (1999). Stakeholder Influence Strategies. Academy of Management Review 24(2):191-205

Goodman, L.E. and Dion, P.A. (2001). The determinants of commitment in the distributormanufacturer relationship. Industrial Marketing Management, 30(3):287-300.

Greenwald, J. (2001). Inside the Ford/Firestone Fight, Time Magazine, Tuesday, May 29.

Grönroos, C (1996). Relationship marketing: strategic and tactical implications. Management Decision, 34(3):5-14

Grönroos, C. (1994). From marketing mix to relationship marketing: towards a paradigm shift in marketing. Management Decision, 32(2):4-20.

Gruen, T. W., Summers, J. O., \& Acito, F. (2000). Relationship marketing activities, commitment and membership behavior in professional associations. Journal of Marketing, 64(3):34-49.

Gundlach, G. T., Achrol, R.S. and Mentzer, J.T. (1995). The structure of commitment in exchange. Journal of Marketing, 59(1): 78-92.

Harrison, J. S., Bosse, D. A., \& Phillips, R. A. (2010). Managing for stakeholders, stakeholder utility functions, and competitive advantage. Strategic Management Journal, 31(1):58-74. 
Hill, R.P., and Martin, K.D. (2014). Broadening the paradigm of marketing as exchange: a public policy and marketing perspective. Journal of Public Policy \& Marketing, 33: $17-33$.

Hillebrand, B., Driessen, P.H. and Koll, O. (2015). Stakeholder marketing: theoretical foundations and required capabilities. Journal of the Academy of Marketing Science, 43:411-428.

Hillman, A. J., and Keim, G. D. (2001). Shareholder value, stakeholder management, and social issues: What's the bottom line? Strategic Management Journal, 22(2):125-139.

Homburg, C. and Griering, A. (2001). Personal Characteristics as Moderators of the Relationship Between Customer Satisfaction and Loyalty-An Empirical Analysis, Psychology \& Marketing, 18(1):43-66.

Hult, G. T. M., Mena, J. A., Ferrell, O. C., \& Ferrell, L. (2011). Stakeholder marketing: a definition and conceptual framework. Academy of Marketing Science Review, 1: 4465.

Jones, T. M. (1995). Instrumental Stakeholder Theory: A Synthesis of Ethics and Economics. Academy of Management Review, 20(2):404-438.

Kochan, T.A and Rubinstein, S.A. (2000). Towards a stakeholder theory of the firm: the Saturn approach. Organization Science, 11, 367-86.

Kotler, P. (2003). Marketing Management: Analysis, Planning, Implementation and Control, $11^{\text {th }}$ Edition. Upper Saddle River N.J.: Prentice Hall.

Macalister, T. and Cross, E. (2000) BP rebrands on a global scale. The Guardian, $25^{\text {th }}$ July.

Maignan, I. and Ferrell, O.C. (2004). Corporate Social Responsibility and Marketing: An Integrative Framework. Journal of the Academy of Marketing Science, 32(1), 3-19.

Maignan, I., Ferrell, O.C. and Ferrell, L. (2005). A stakeholder model for implementing social responsibility in marketing. European Journal of Marketing, 39, 956-977.

Massey, G.R. and Dawes, P.L. (2007). Personal characteristics, trust, conflict, and effectiveness in marketing/sales working relationships. European Journal of Marketing, 41, 9/10, 1117-1145.

Mena, J.A. and Chabowski, B.R. (2015) The role of organizational learning in stakeholder marketing. Journal of the Academy of Marketing Science, 43:429-452.

Miller, R.L. and Lewis, W.F. (1991). A stakeholder approach to marketing management using the value exchange models. European Journal of Marketing, 25(8), 55-68.

Miles, S. (2017a) Stakeholder theory classification: A theoretical and empirical evaluation of definitions. Journal of Business Ethics, 142(3), 437-459. 
Miles, S. (2017b) Stakeholder theory classification, definitions and essential contestability, in Wasieleski, D.M and Weber, J. (eds.), Stakeholder Management, Business \& Society 360, Bingley: Emerald, 21-47.

Mitchell, R.K., Agle, B.R. and Wood, D.J. (1997). Towards a Theory of Stakeholder Identification and Salience: Defining the Principle of Who and What Really Counts. Academy of Management Review, 22/4 :853-886.

Morgan, R.M. and Hunt, S.D. (1994). The commitment-trust theory of relationship marketing. Journal of Marketing, 58(3):2-38.

Murphy, B., Maguiness, P., Pescott, C., Wislang, S., Ma, J. and Wang, R. (2005). Stakeholder perceptions presage holistic stakeholder relationship marketing performance. European Journal of Marketing, 39(9/10):1049-1069.

Nguyen, B. (2012). The dark side of customer relationship management: Exploring the underlying reasons for pitfalls, exploitation and unfairness. Journal of Database Marketing \& Customer Strategy Management 19, 56-70.

Orth, U.R. and Green, M.T. (2009) Consumer loyalty to family versus non-family business: the roles of store image, trust and satisfaction. Journal of Retailing and Consumer Services, 16, 4, pp. 248-259.

Palmatier, R.W., Dant, R.P, Grewal, D. and Evans, K.R. (2006). Factors influencing the effectiveness of relationship marketing: A meta-analysis. Journal of Marketing, 70:136-153.

Palmer, A. and Huo, Q. (2013). A study of trust over time within a social network mediated environment. Journal of Marketing Management, 29(15-16):1816-1833

Payne, A. and Holt, S. (2001). Diagnosing customer value: integrating the value process and relationship marketing. British Journal of Management, 12(2):159-182.

Payne, A. and Frow, P (2006). Customer relationship management form strategy to implementation. Journal of Marketing Management, 22(1/2):135-68

Payne A., Ballantyne D. and Christopher M. (2005). A stakeholder approach to relationship marketing strategy. European Journal of Marketing, 39(7/8): 855-871.

Payne, A., Storbacka, K. and Frow, P. (2009). Co-creating brands: diagnosing and designing relationship experience. Journal of Business Research, 62(3):379-89.

Phillips, R.A. (2003). Stakeholder Theory and Organizational Ethics. San Francisco: BerrettKoehler. 
Podnar, K. and Jancic, Z. (2006). Towards a Categorization of Stakeholder Groups: An Empirical Verification of a Three-Level Model. Journal of Marketing Communication, 12(4):297-308.

Polonsky, M.J. (1996). Stakeholder management and the stakeholder matrix: Potential strategic marketing tools. Journal of Market Focused Management, 1(3):209-229.

Polonsky, M. J. and Scott, D. (2005). An empirical examination of the stakeholder strategy matrix. European Journal of Marketing, 39(9/10): 1199-1215.

Polonsky, M.J. and Ottman, J. (1998). Stakeholders' contribution to the green new product development process. Journal of Marketing Management, 14, 533-57.

Polonsky, M.J., Suchard H.T., Scott, D.R. (1999). The incorporation of interactive external environment: A stakeholder approach. Journal of Strategic Marketing, 7(1):41-55.

Prahalad,C.K. and Ramaswamy, V (2004). Co-creation experiences: The next practice in value creation. Journal of Interactive Marketing, 18 (3):5-14

Rowley, T. J. and Moldoveanu, M. (2003). When will stakeholder groups act? An interest and identity based model of stakeholder group mobilization. Academy of Management Review, 28(2): 204-219.

Rowley, T.J. (1997). Moving beyond dyadic ties: A network theory of stakeholder influences. Academy of Management Review, 22:885-910.

Savage, G. T., Nix, T. W., Whitehead, C. J. and Blair, J. D. (1991). Strategies for Assessing and Managing Organizational Stakeholders. Academy of Management Executive, 5/2: $61-75$.

Sirdeshmukh, D., Singh, J., \& Sabol, B. (2002). Consumer trust, value and loyalty in relational exchanges. Journal of Marketing, 66(1), 15-37.

Stearns, J.M., Walton, J.R., Crespy, C.T. and Bol, J.W. (1996). The role of moral obligations to stakeholders in ethical marketing decision-making. The Journal of Marketing Management, 6 (2):34-47

Taylor, V. (2010). The most imaginative CSR ad campaigns. Forbes, $7^{\text {th }}$ September.

Theron, E. and Terblanche, N.S. (2010). Dimensions of relationship marketing in businessto-business financial services, International Journal of Market Research, 52(3):383402.

Vargo, S.L. and Lusch, R.F. (2004) Evolving to a New Dominant Logic for Marketing. Journal of Marketing, 68 (January):1-17 
Verhoef, P. C. (2003). Understanding the effect of customer relationship management efforts on customer retention and customer share development. Journal of Marketing, 67(4):30-45.

Webster, F. E., Jr., \& Lusch, R. F. (2013). Elevating marketing: marketing is dead! long live marketing! Journal of the Academy of Marketing Science, 41, 389-399.

Wheeler, B. (2013). Tesco and a strange bit of poetry. BBC News Magazine, $8^{\text {th }}$ March.

Whysall, P. (2000). Addressing Ethical Issues in Retailing: A Stakeholder Perspective. International Review of Retail, Distribution and Consumer Research, 10/3: 305-318.

Zadek, S. and Raynard, P. (2002). Stakeholder Engagement: Measuring and Communicating the Quality. Accountability Quarterly, 19: 8-17. 
Figure 1 A Ladder of Stakeholder Management and Engagement

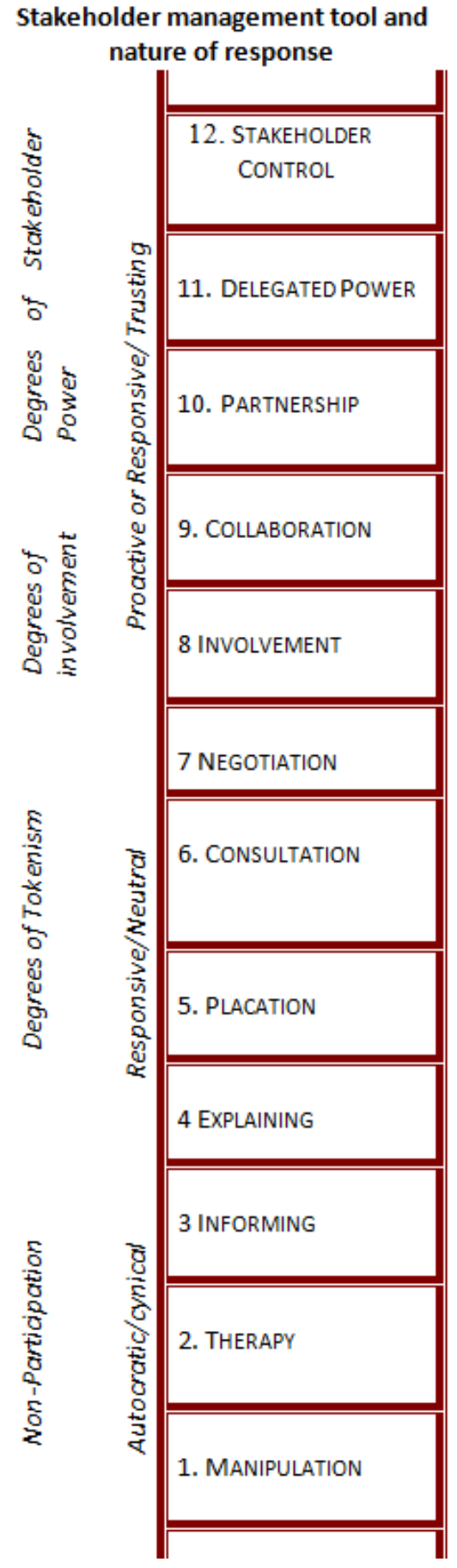

Intention of engagement

Majority representation of stakeholders in decision making process

Minority representation of stakeholders in decision making process

Joint decision making power over specific projects

Some decision making power afforded to stakeholders over specific projects

Stakeholders provide conditional support; if conditions are not met support is removed. The organization decides the extent of conformity

Organization has the right to decide. Stakeholders can advise.

Appease the stakeholder Stakeholders can hear and be heard, but have no assurance of being heeded by the organization

Educate stakeholders

Educate stakeholders

'Cure' stakeholders of their ignorance and preconceived beliefs

'Misleading' stakeholders, attempting to change stakeholder expectations
Level of influence

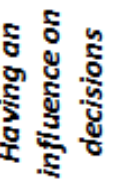

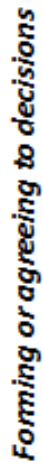

Style of dialogue and associated examples

Multi-way dialogue e.g. Community projects

Multi-way dialogue e.g. Board representation

Multi-way dialogue e.g., joint ventures

Multi-way dialogue e.g. strategic alliances

Multi-way dialogue e.g. constructive dialogue

Multi-way dialogue e.g. Reactive: Bargaining

Two-way dialogue e.g. questionnaires, interviews, focus groups, task forces, advisory panels

Two-way dialogue e.g. Workshops

One-way dialogue e.g. verified corporate social reports

One-way dialogue e.g. briefing sessions, leaflets, magazines, newsletters, green glossy social corporate reports or other publications

Source: Friedman and Miles (2006:162) 
Table 1: Dimensions of Relationship Quality

\begin{tabular}{|c|c|}
\hline Dimension & $\begin{array}{c}\text { Definition } \\
\end{array}$ \\
\hline $\begin{array}{l}\text { D1. Attractiveness of } \\
\text { alternatives }\end{array}$ & $\begin{array}{l}\text { Clients' estimate of the likely satisfaction available in an } \\
\text { alternative relationship }\end{array}$ \\
\hline D2. Bond & $\begin{array}{l}\text { The (psychological process through which the buyer and the } \\
\text { provider build a relationship to the benefit of both parties }\end{array}$ \\
\hline D3. Commitment & $\begin{array}{l}\text { The desire for continuity manifested by the willingness to invest } \\
\text { resources in a relationship }\end{array}$ \\
\hline D4. Communication & $\begin{array}{l}\text { The formal as well as informal sharing of meaningful and timely } \\
\text { information between firms }\end{array}$ \\
\hline D5. Competence & $\begin{array}{l}\text { The buyer's perception of the supplier's technological and } \\
\text { commercial competence }\end{array}$ \\
\hline D6. Conflict & The overall level of disagreement in the working partnership \\
\hline D7. Cooperation & $\begin{array}{l}\text { Similar or complimentary coordinated actions taken by firms in } \\
\text { interdependent relationships to achieve mutual outcomes or } \\
\text { singular outcomes with expected reciprocation over time }\end{array}$ \\
\hline D8. Coordination & $\begin{array}{l}\text { The extent to which different parties in a relationship work well } \\
\text { together to accomplish a collective set of tasks }\end{array}$ \\
\hline D9. Customisation & $\begin{array}{l}\text { The extent to which a seller uses knowledge about a buyer to } \\
\text { tailor his offerings to the buyer }\end{array}$ \\
\hline D10. Dependence & $\begin{array}{l}\text { The extent to which there is no equivalent of better alternatives } \\
\text { available in the market }\end{array}$ \\
\hline D11. Empathy & Seeking to understand the desires and goals of someone else \\
\hline $\begin{array}{l}\text { D12. Goal compatibility/ } \\
\text { goal congruence }\end{array}$ & $\begin{array}{l}\text { The degree to which partners share goals that could only be } \\
\text { accomplished through joint action and maintenance of the } \\
\text { relationship }\end{array}$ \\
\hline $\begin{array}{l}\text { D13. Opportunistic } \\
\text { behaviour }\end{array}$ & $\begin{array}{l}\text { The behaviour of a party that endangers a relationship for the } \\
\text { purpose of taking advantage of a new opportunity }\end{array}$ \\
\hline D14. Power & $\begin{array}{l}\text { The ability of one individual or group to control or influence the } \\
\text { behaviour of another }\end{array}$ \\
\hline D15. Reciprocity & $\begin{array}{l}\text { The component of a business relationship that causes either } \\
\text { party to provide favours or make allowances for the other in } \\
\text { return for similar favours or allowances at a later stage }\end{array}$ \\
\hline D16. Relationship benefits & $\begin{array}{l}\text { Partners that deliver superior benefits will be highly valued and } \\
\text { firms will commit themselves to establishing, developing and } \\
\text { maintaining relationships with such parties }\end{array}$ \\
\hline $\begin{array}{l}\text { D17. Relationship-specific } \\
\text { investment. }\end{array}$ & $\begin{array}{l}\text { The relational-specific commitment of resources that a partner } \\
\text { invests in the relationship }\end{array}$ \\
\hline D18. Satisfaction & $\begin{array}{l}\text { An overall evaluation based on the total purchase and } \\
\text { consumption experience with a good or service over time }\end{array}$ \\
\hline D19. Service quality & A comparison between customer expectations and performance \\
\hline $\begin{array}{l}\text { D20. Shared values/ } \\
\text { similarity }\end{array}$ & $\begin{array}{l}\text { The extent to which partners have beliefs in common about what } \\
\text { behaviours, goals and policies are important, appropriate or } \\
\text { inappropriate, and right or wrong }\end{array}$ \\
\hline D21.Switching costs & $\begin{array}{l}\text { The one-time costs that customers associate with the process of } \\
\text { switching from one provider to another }\end{array}$ \\
\hline D22. Trust & $\begin{array}{l}\text { A willingness to rely on an exchange partner in whom one has } \\
\text { confidence }\end{array}$ \\
\hline D23. Uncertainty & $\begin{array}{l}\text { The anticipated changes in the circumstances surrounding an } \\
\text { exchange }\end{array}$ \\
\hline
\end{tabular}

Source: Adapted from Athanasopolou (2009) and Theron and Terblanche (2010) 
Figure 2 Trust, Stakeholder Engagement and Dimensions of Relationship Quality

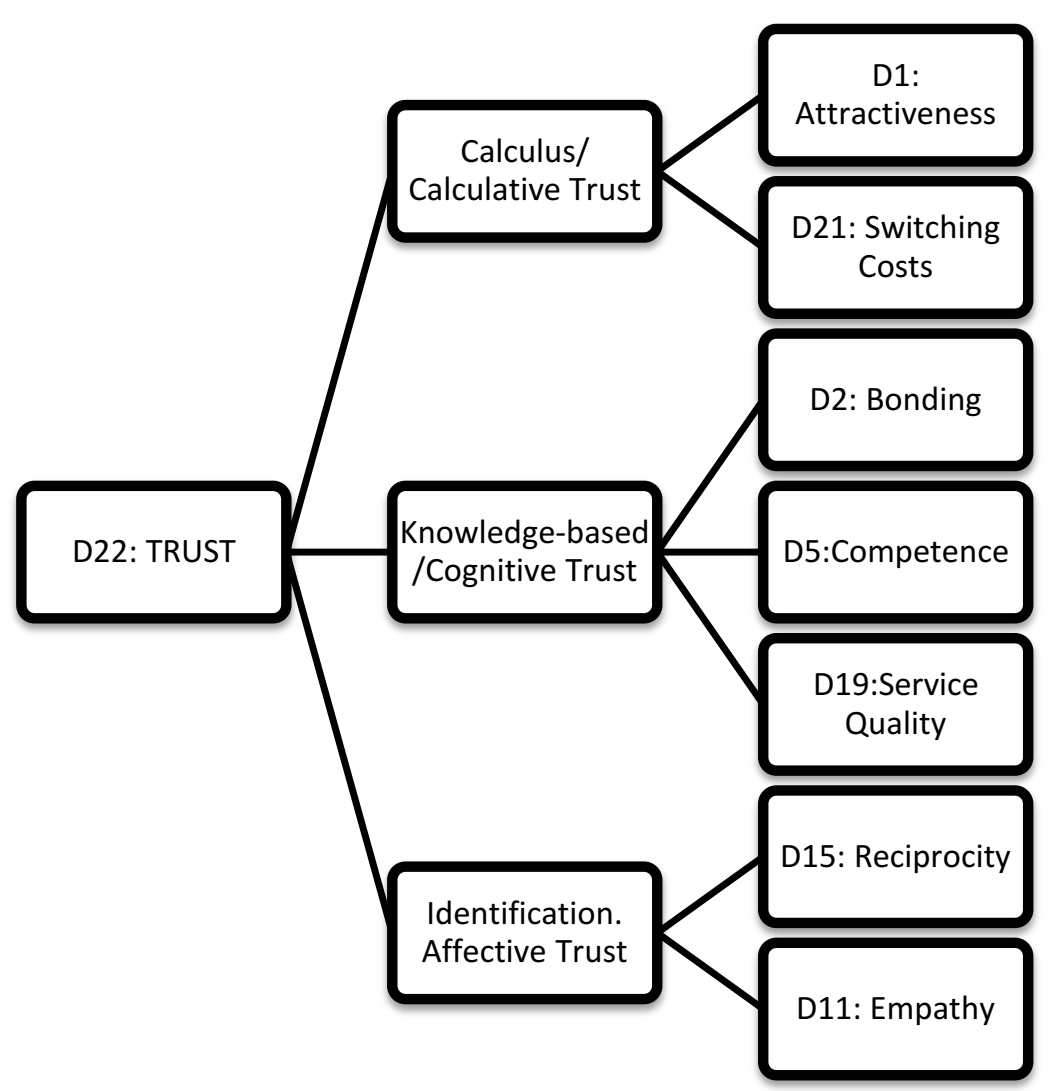

D13: Opportunistic behaviour

D7:Low Cooperation

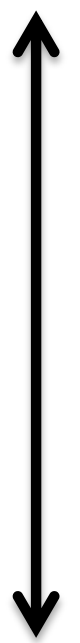

High cooperation Predictability 
Figure 3 Commitment, Stakeholder Strategies and Dimensions of Relationship Quality
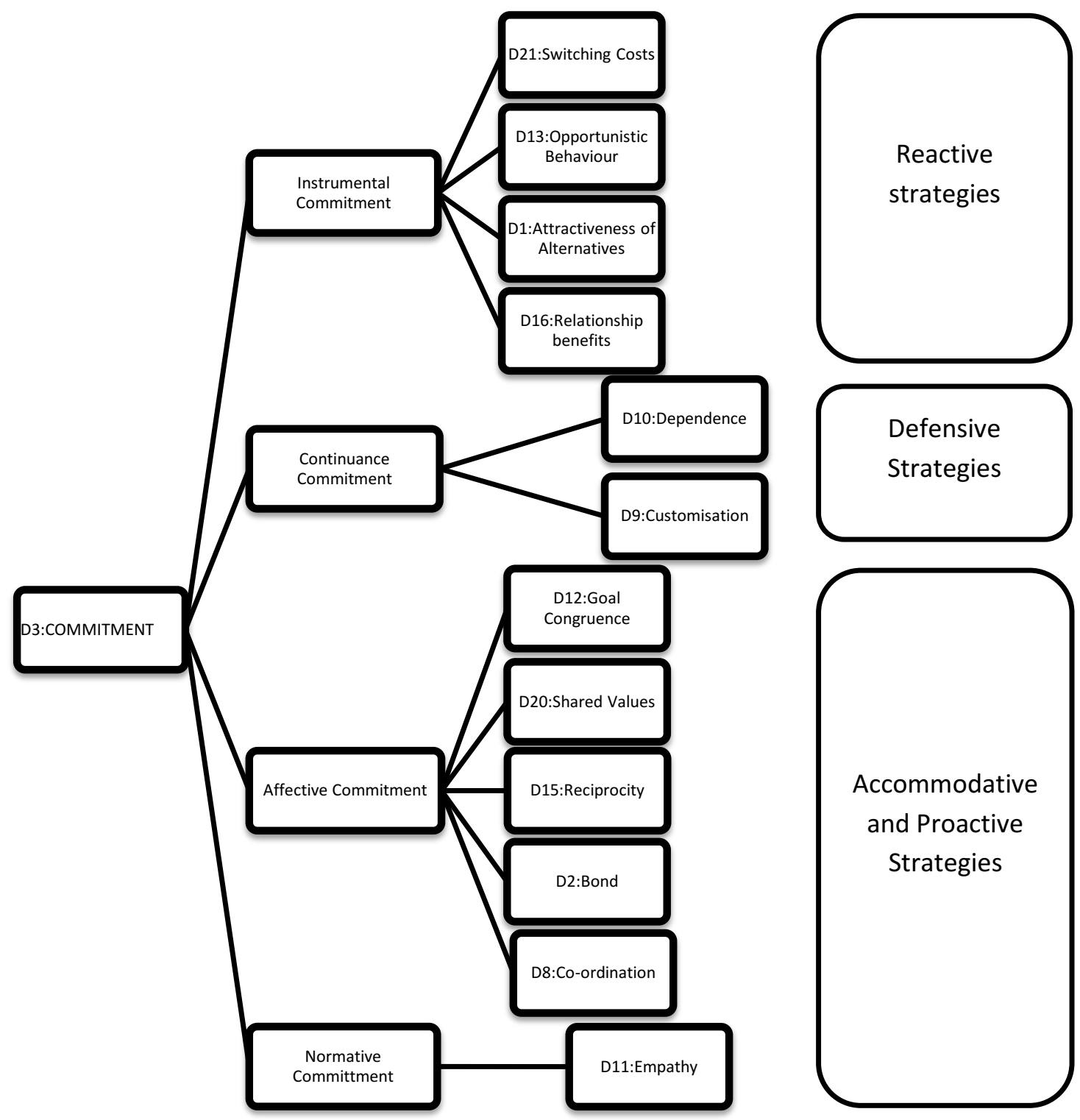


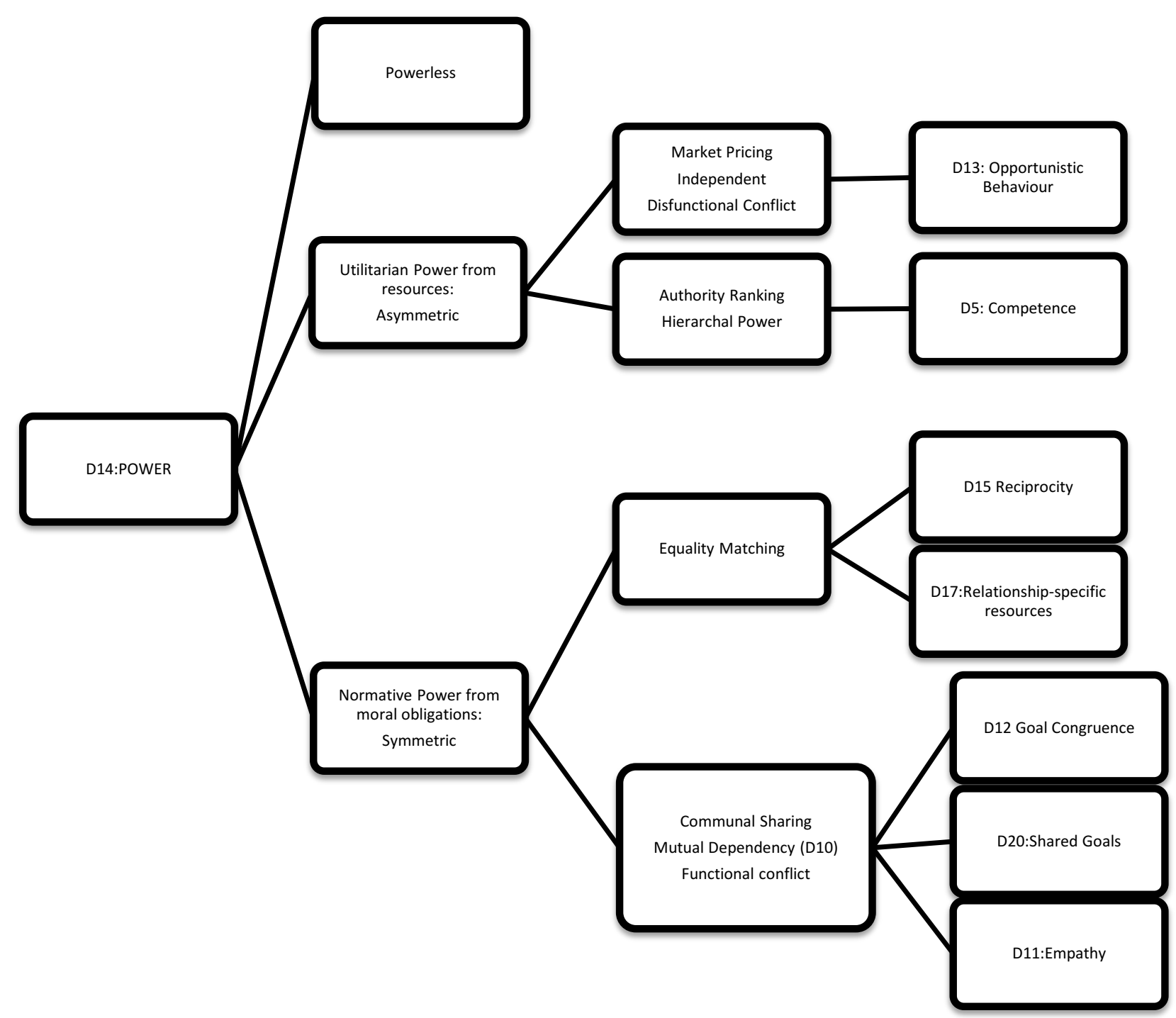


Figure 5: A Stakeholder Marketing Ladder of Engagement

\begin{tabular}{|c|c|c|}
\hline \multicolumn{3}{|c|}{ RELATIONSHIP DIMENSIONS } \\
\hline TRUST & COMMITMENT & POWER \\
\hline \multirow[t]{2}{*}{ 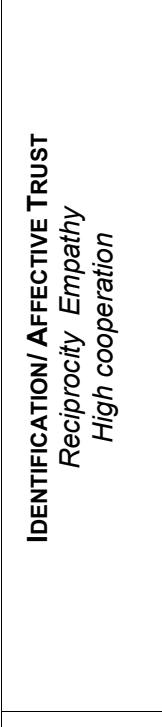 } & 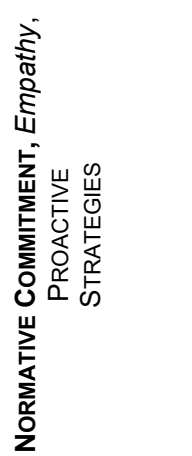 & 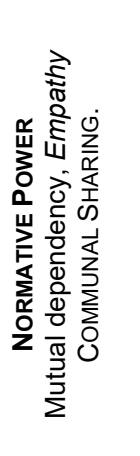 \\
\hline & 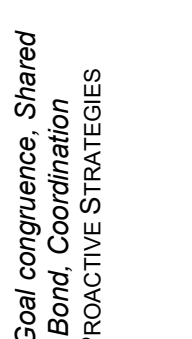 & 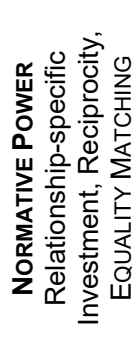 \\
\hline \multirow{2}{*}{ 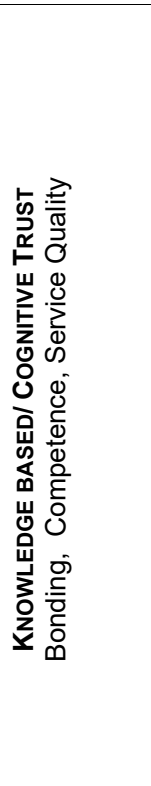 } & 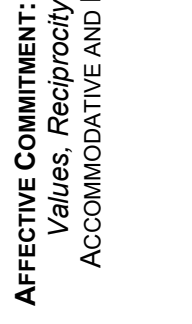 & \multirow{2}{*}{ 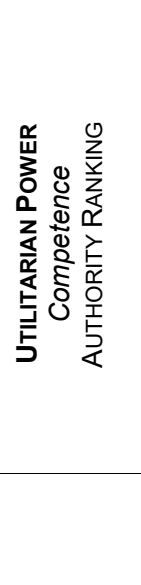 } \\
\hline & 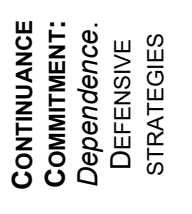 & \\
\hline \multirow{2}{*}{ 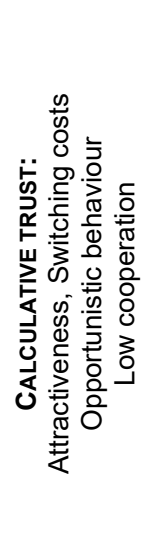 } & \multirow{2}{*}{ 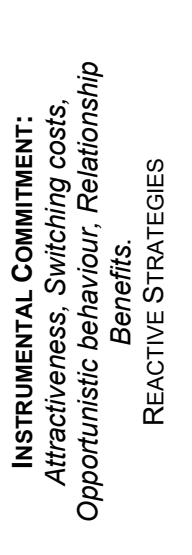 } & 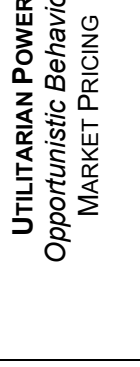 \\
\hline & & 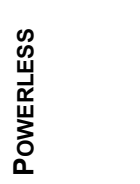 \\
\hline
\end{tabular}

ENGAGEMENT LEVELS

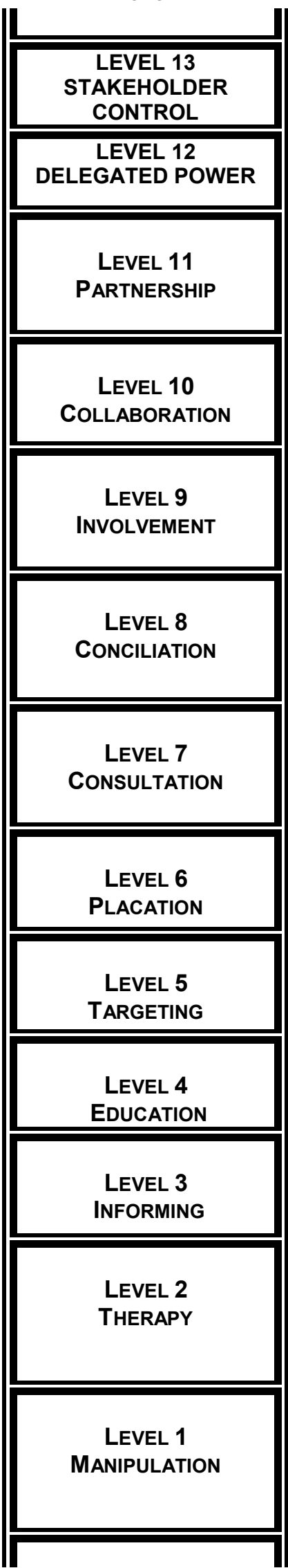

\section{EXAMPLES}

Community projects

Board representation. Business-tobusiness models where control is passed to supplier

Joint ventures to develop products: Genuine cocreation with a range of stakeholders. Equal

business-to-business collaborations

Strategic alliances based on shared goals to develop products. Development in CSR will be linked to green or cause related marketing

Reactive: Sponsorship or endorsements to improve image. Proactive: Co-creation with 'prosumers', sharing proprietary information. Ideation contest in which winning idea is determined by vote

Reactive responses to stakeholder conciliation via service desks. Proactive engagement to build trust and loyalty e.g. product recalls, learning from complaints

Stakeholder opinion is valuable. Views are solicited via surveys, focus groups, advisory panels, social media forums, secret shopper.

Response to stakeholder concerns e.g. labelling or packaging, customer service, CSR advertising, green or cause related marketing

Behaviour analysis via data management. Telemarketing, triggered and targeted offers. Customisation, cross-selling, up-selling

Raising awareness. Use of social media and blogs, 'Infomercials', CSR advertising

Product launch, special editions, time limited offers

'Curing' ignorance via self-laudatory PR as reactive response to problems. One way, static advertising:

billboards, flyers, magazine, newspaper, TV, internet adverts

Aim to influence choice through manipulative tactics 